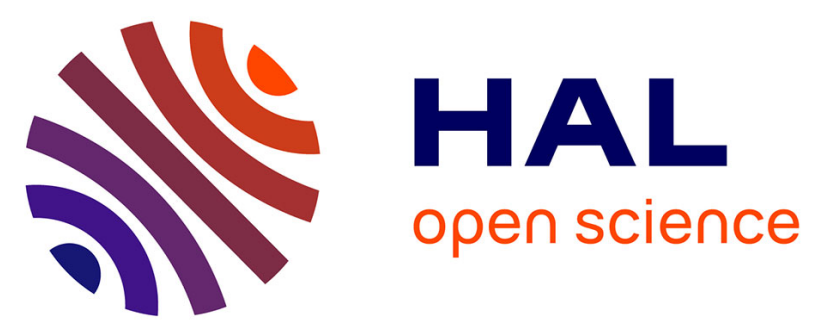

\title{
Influence of molybdenum oxide on structural, optical and physical properties of oxychloride glasses for nonlinear optical devices
}

F. Goumeidane, M. Iezid, B. Melik, K. Ouannes, M. Legouera, M. Poulain, T. Satyanarayana, P.S. Prasad, P.V. Rao

\section{To cite this version:}

F. Goumeidane, M. Iezid, B. Melik, K. Ouannes, M. Legouera, et al.. Influence of molybdenum oxide on structural, optical and physical properties of oxychloride glasses for nonlinear optical devices. Ceramics International, 2017, 43 (14), pp.11305-11311. 10.1016/j.ceramint.2017.05.329 . hal-01581243

HAL Id: hal-01581243

https://hal-univ-rennes1.archives-ouvertes.fr/hal-01581243

Submitted on 4 Sep 2017

HAL is a multi-disciplinary open access archive for the deposit and dissemination of scientific research documents, whether they are published or not. The documents may come from teaching and research institutions in France or abroad, or from public or private research centers.
L'archive ouverte pluridisciplinaire HAL, est destinée au dépôt et à la diffusion de documents scientifiques de niveau recherche, publiés ou non, émanant des établissements d'enseignement et de recherche français ou étrangers, des laboratoires publics ou privés. 


\title{
ACCEPTED MANUSCRIPT
}

Influence of molybdenum oxide on structural, optical and physical properties of oxychloride glasses for nonlinear optical devices

Goumeidane $\mathrm{F}^{\mathrm{a}}$, Iezid $\mathrm{M}^{\mathrm{a}}$, Melik $\mathrm{B}^{\mathrm{a}}$, Ouannes $\mathrm{K}^{\mathrm{b}}$, Legouera $\mathrm{M}^{\mathrm{c}}$, Poulain $\mathrm{M}^{\mathrm{d}}$, $\mathrm{T}$. Satyanarayana ${ }^{\mathrm{e}}$, P. Syam Prasad ${ }^{\mathrm{f}}$, P. Venkateswara Rao ${ }^{\mathrm{g}^{*}}$

${ }^{a}$ Laboratoire de Génie Mécanique, université de Biskra, BP 145, Biskra, Algeria

${ }^{\mathrm{b}}$ Faculté des Sciences et de la Technologie, Université de Biskra, BP 145, Biskra, Algeria

`Laboratoire de Génie Mécanique et Matériaux, Université de Skikda, 21000, Algeria

dinstitut Sciences Chimiques, Université de Rennes1, Campus Beaulieu, F-35042 Rennes

${ }^{\mathrm{e}}$ Dept. of Electronics \& Instrumentation Engineering, Lakireddy Bali Reddy College of Engineering (A), Mylavaram, Krishna 521230, A.P., India

fDept. of Physics, National Institute of Technology (NIT), Warangal-506 004, Telangana State, India

${ }^{g}$ Department of Physics, The University of the West Indies, Mona Campus, Kingston 7, Jamaica

*Corresponding author : pvrao54@gmail.com

\begin{abstract}
The unconventional Heavy Metal Oxide Glasses (HMOG) are characterized by a low phonon energy, large infrared range transmission, high refractive index and nonlinear optical properties. Ternary glasses have been synthesized and studied in the $\mathrm{Sb}_{2} \mathrm{O}_{3}-$ $\mathrm{MoO}_{3}-\mathrm{ZnCl}_{2}$ system. Further, the glass formation compositional limits are reported and some glass samples with the formula: $(90-\mathrm{x}) \mathrm{Sb}_{2} \mathrm{O}_{3}-\mathrm{xMoO}_{3}-10 \mathrm{ZnCl}_{2}(10 \leq \mathrm{x} \leq 50$, mole $\%)$ were elaborated. Thermal properties have been measured and indicating that the glass transition temperature decreases with increasing proportions of molybdenum oxide. The evolution of density, microhardness and elastic modulus has been studied as functions of parameter $\mathrm{x}$ and Raman spectra measurements have been shown the partial conversion of $\mathrm{MoO}_{6}$ octahedral units into $\mathrm{MoO}_{4}$ tetrahedral.
\end{abstract}

Keywords: Oxychloride glasses; Density; Raman, Elastic properties; Optical properties

\section{Introduction}




\section{ACCEPTED MANUSCRIPT}

Over the past few years, several researches have been carried out on antimony glasses. Binary and ternary $\mathrm{Sb}_{2} \mathrm{O}_{3}$-based glasses have been studied, including various oxide [1-6], oxysulphide [7, 8] and oxychloride systems $[9,10]$. These glasses are used in nonlinear optical devices particularly in broadband optical amplifiers functioning about $1.5 \mu \mathrm{m}[11]$.

Molybdenum oxide is considered as a glass former that requires the presence of other elements to form a glass. Molybdate glasses are obtained by introducing another network-forming oxide such as $\mathrm{Sb}_{2} \mathrm{O}_{3}, \mathrm{P}_{2} \mathrm{O}_{5}, \mathrm{TeO}_{2}$...etc. The molybdate glasses are used for high-density memories, light modulation, large area display devices like smart windows and other electrochromic systems $[12,31,32]$. The different oxidation states of molybdenum are: $\mathrm{Mo}^{6+}, \mathrm{Mo}^{5+}, \mathrm{Mo}^{4+}$ and $\mathrm{Mo}^{3+}$. In the molybdate glasses, different works suggest the existence of molybdenum in the $\mathrm{Mo}^{6+}$ form which is the most stable [13]. Rada et al [14] suggest that a part of the $\mathrm{Mo}^{6+}$ ions is converted into $\mathrm{Mo}^{3+}$ and $\mathrm{Mo}^{5+}$ ions. This process causes the depolymerisation of host glass network. The molybdenum oxide is formed in the glass by different structures, like structural units of octahedron and tetrahedron units such as $\mathrm{MoO}_{6}$ and $\mathrm{MoO}_{4}$ respectively. Krapchanska et al [15] showed a partial conversion of $\mathrm{MoO}_{6}$ to $\mathrm{MoO}_{4}$ units in the $\mathrm{MoO}_{3}-\mathrm{TiO}_{2}-\mathrm{Bi}_{2} \mathrm{O}_{3}$ system. Subcik et al [16] also showed that the incorporation of $\mathrm{MoO}_{3}$ units in the $\mathrm{ZnO}$ $\mathrm{B}_{2} \mathrm{O}_{3}-\mathrm{P}_{2} \mathrm{O}_{5}$ glasses revealed the increase of the $\mathrm{MoO}_{6} / \mathrm{MoO}_{4}$ ratio.

$\mathrm{Sb}_{2} \mathrm{O}_{3}$ contributes in the glass network with $\mathrm{SbO}_{3}$ structural units and it appears tetrahedra with the oxygens to be found at three corners and the lone pair of electrons of antimony $\mathrm{Sb}^{3+}$ at the fourth corner localized in the third equatorial direction of the $\mathrm{Sb}$ atom. There may be a possibility of existence of antimony ions in the $\mathrm{Sb}^{5+}$ state and participate in the glass network forming with $\mathrm{Sb}^{5+} \mathrm{O}_{4}$ structural units may enhance the nonlinear optical properties [11]. In $\mathrm{Sb}_{2} \mathrm{O}_{3}$ based glasses the addition of transition metal 


\section{ACCEPTED MANUSCRIPT}

oxide $\mathrm{MoO}_{3}$ improves functionality of glasses for their desired optical applications. Particularly, $\mathrm{MoO}_{3}$ shows interesting optoelectronic features and can control phase separation in glasses [43].

The aim of this paper is focuses on the elaboration of a new antimony oxychloride glass from the $\mathrm{Sb}_{2} \mathrm{O}_{3}-\mathrm{MoO}_{3}-\mathrm{ZnCl}_{2}$ system. We are interested by molybdenum rates incorporated into the glass, its effect on the different physical properties that have been measured, and especially in the structural study by Raman measurements. Physical properties such as: density, energy dispersive spectroscopy (EDS), differential scanning calorimetry (DSC), optical transmission, microhardness and elastic moduli have also been considered in terms of molybdenum influence.

\section{Experimental}

In this present study, the starting materials $\mathrm{Sb}_{2} \mathrm{O}_{3} \geq 99 \%$ (Acros), $\mathrm{ZnCl}_{2} \geq 99.8 \%$ (Merck) and $\mathrm{MoO}_{3} \approx 99 \%$ (Acros) are used for the synthesis of the glass samples. Meltquenching is the process of synthesis. The powders are mixed thoroughly in a mortar with the mean batch weight around $5 \mathrm{~g}$. The mixture is inserted into a silica glass tube, about $10 \mathrm{~mm}$ in diameter and then subjected to a flame until a clear liquid obtaining. The bath of fusion is cast in a mould under preheated brass plate around $200{ }^{\circ} \mathrm{C}$. The samples obtained (thickness of a few millimetres) are placed in the furnace at a temperature lower than the temperature of vitreous transition with a slow heating rate. After annealing, the samples were polished for physical measurements.

The glass composition was analyzed by the (EDS) energy dispersive spectroscopy (JSM 6400 Jeol and Oxford link ISIS). With the help of crystalline materials references, experimental error is estimated to be $1 \%$ for $\mathrm{Sb}$, Mo and $\mathrm{Zn}, 2 \%$ 
for $\mathrm{Cl}$ and $5 \%$ of oxygen. Density was determined using a helium pycnometer (Micromeritics, AccuPyc 1330) with $\pm 0.001 \mathrm{~g} / \mathrm{cm}^{3}$ accuracy.

Thermal properties of the samples were measured by the differential scanning calorimetry (DSC 2010 from TA Instruments) at the heating rate of $10 \mathrm{~K} / \mathrm{min}$ with the sensitivity better than $0.1{ }^{0} \mathrm{C}$. The estimated accuracy is $\pm 2 \mathrm{~K}$ for the glass transition temperature $\mathrm{Tg}$, crystallization temperature $\mathrm{Tx}$ and $\pm 1 \mathrm{~K}$ for the temperature of the crystallization of peak. Tx-Tg provides the stability against devitrification. The DSC signals showed no crystallization peaks indicating that these glasses are having a very low tendency to crystallization and exhibiting extremely high thermal stability. Thermal stability is the important property of glasses and gives the measure of the degree of disorder of glassy state.

The analysis of the vitreous samples was carried out by the Raman spectroscopy in the range of $1100 \mathrm{~cm}^{-1}$ to $100 \mathrm{~cm}^{-1}$ by Sentra- Bruker. Varian Cary 5 spectrometer was used to record the optical transmission in the UV-visible spectrum between 400 and $800 \mathrm{~nm}$ and Bomem Michelson 100 IR spectrometer was employed for the infrared spectrum in between 500 and $4000 \mathrm{~cm}^{-1}$.

The Matzuzawa MXT 70 digital microhardness was used with $100 \mathrm{~g}$ as load to measure the microhardness values. Ultrasonic measurements were taken by the pulse echo method using a Panametrics model 5800 pulser/receiver with a quartz transducer. Both X-cut transducer and Y-cut transducer (with $10 \mathrm{MHz}$ frequency) were employed for both longitudinal and shear modes. A Hewlett-Packard model 54502A oscilloscope recorded the pulse transient. Young's modulus E, bulk modulus K, and shear modulus $\mathrm{G}$ were measured by the following equations [33]: 


$$
\begin{aligned}
& E=\frac{\rho V_{T}^{2}\left(3 V_{L}^{2}-4 V_{T}^{2}\right)}{\left(V_{L}^{2}-V_{T}^{2}\right)} \\
& K=\frac{\rho\left(3 V_{L}^{2}-4 V_{T}^{2}\right)}{3} \\
& G=\rho V_{T}^{2}
\end{aligned}
$$

Where $\rho=$ Density of the glass sample

$V_{T}=$ Transversal ultrasonic velocity

$V_{L}=$ Longitudinal ultrasonic velocity

The uncertainty is estimated to be about $\pm 2 \%$ for elastic modulus.

\section{Results and discussion}

\subsection{Physical properties}

Chemical composition, some experimental properties of SMZ glasses are provided in Table 1. Fig. 1 shows the Oxy-halogenated glass area for ternary system. The glass matrix $\mathrm{Sb}_{2} \mathrm{O}_{3}-\mathrm{MoO}_{3}-\mathrm{ZnCl}_{2}$ was characterized by its extensive glass area and exceptional thermal stability. We have chosen to vary the molybdenum oxide, which is an excellent effect in heating homogenization $[17,18]$. It is used for its electrochromic properties [19] and especially for improving the conductivity by the ionic and electronic input $[20,21]$. A series of ternary system bulk samples were prepared for the physical measurements and were represented by the lines in Fig. 1 with the formula: (90-x) $\mathrm{Sb}_{2} \mathrm{O}_{3}-\mathrm{xMoO}_{3}-10 \mathrm{ZnCl}_{2}(10 \leq \mathrm{x} \leq 50)$ called «SMZ». The molar concentration of $\mathrm{MoO}_{3}$ is given by the number that follow the letters SMZ.

Glass compositions of the prepared samples were studied by the EDS spectra. Fig. 2 shows the chemical composition spectra of the sample SMZ20. In Table 1 it is clear from the chemical composition of the glasses that the differences between the 


\section{ACCEPTED MANUSCRIPT}

nominal and analysed cations compositions remain weak. These results indicate that the losses induced by evaporation during fusion are very limited. Silicon traces lower than $1 \%$ are observed in all the samples, due to crucible contamination. The measurement of concentration refers to the three analysed elements. Discrepancies are larger for anions; this can be explained by the limited accuracy of the EDS technique for light elements, particularly for the oxygen. Uncertainty related to electronic scan microscopy results is about $1 \%$.

The density and molar volume of the glass samples decreases linearly with the substitution of the antimony oxide and molybdenum oxide. The density of a solid glass is a function of its composition; in fact, it is directly depends on the atomic weight of each component as well as the volume occupied by these components [22]. This reduction is due to the lower atomic weight of the molybdenum than the antimony.

\subsection{Thermal properties}

DSC curves for different glasses are shown in Fig. 4. The characteristic temperatures of the glass samples have been measured for the glass series $(90-\mathrm{x}) \mathrm{Sb}_{2} \mathrm{O}_{3}$ $\mathrm{xMoO}_{3}-10 \mathrm{ZnCl}_{2}$. The thermal stability $\mathrm{Tx}-\mathrm{Tg}$, exceeds $100{ }^{\circ} \mathrm{C}$ for all the glass samples (Table 2). The numerical values obtained from the DSC curves provides the information on stability against devitrification $(20 \mathrm{~K} / \mathrm{min})$. As shown in Table 2 , from the results of DSC, when the concentration of $\mathrm{MoO}_{3}$ increases from 10 to $50 \%$, the glass transition temperature decreases linearly (Fig. 5), indicates the decreasing bonding strength of the material. Goumeidane et al. [10] was mentioned that an excess of anionic oxygen which causes the increase of the nonbridging oxygen in the vitreous network. This conclusion could explain the decreased values of transition temperature Tg in the glass system. 


\section{ACCEPTED MANUSCRIPT}

\subsection{Optical properties}

In the infrared spectrum, the glasses can transmit up to $1800 \mathrm{~cm}^{-1}$ (Fig. 6). The spectrum shows a large absorption band around $3300 \mathrm{~cm}^{-1}$, originates from $\mathrm{OH}$ groups. A second extrinsic absorption band is observed between 1700 and $1900 \mathrm{~cm}^{-1}$, which limits the effects of the optical transmission of these glasses. It corresponds to the first harmonic of the fundamental of Si-O vibration band at $1984 \mathrm{~cm}^{-1}$ and arises probably from silicate anions from glass crucibles. The multiphonon absorption cannot be identified accurately under these conditions. Generally, due to low phonon energy of the oxyfluoride or oxychloride glasses, when rare earth ions are doped into them, the multiphonon relaxation rates are reduced from emitting levels to lower states, which causes the quantum efficiencies to increase for various photonic applications[44,45]. UV-visible depends on the energy band gap between the valence and conduction electronic layers of material. It has been determined by the Urbach method. The UVvisible spectrum for $50 \mathrm{Sb}_{2} \mathrm{O}_{3}-40 \mathrm{MoO}_{3}-10 \mathrm{ZnCl}_{2}$ glass sample (2.5 $\mathrm{mm}$ in thickness) has been shown in Fig. 7 and the UV-visible transmission edge was around $516 \mathrm{~nm}$. Fig. (7) shows the Urbach plot of $50 \mathrm{Sb}_{2} \mathrm{O}_{3}-40 \mathrm{MoO}_{3}-10 \mathrm{ZnCl}_{2}$ glass sample. The value of optical band gap obtained from the extrapolation of the curve is $2.39 \mathrm{eV}$.

\subsection{Raman spectra}

The Raman spectra (Fig. 8) of the ternary system's vitreous samples are recorded at ambient temperature in the spectral range $1500-50 \mathrm{~cm}^{-1}$. The broad peaks and Boson peak confirm the glassy state below $100 \mathrm{~cm}^{-1}$, which is ubiquitous in the Raman spectra of disordered solids, especially of glasses. The presence of the Boson peak in the Raman spectra affirms the vitreous state of material [6] which has not an equivalent in the crystalline materials. The Raman spectra of SMZ 10 glasses reveal the 


\section{ACCEPTED MANUSCRIPT}

presence of the band at $416 \mathrm{~cm}^{-1}$, related to symmetric stretching vibrations of the pyramids $\mathrm{SbO}_{3}$ and $\mathrm{ZnO}_{4}$ units. This band intensity decreases with the increase of $\mathrm{MoO}_{3}$ from $10 \%$ to $30 \%$. We recorded a small shift in the SMZ 20 and SMZ 30 samples, associated with the same vibration mode, they are toward $424 \mathrm{~cm}^{-1}$ and 413 $\mathrm{cm}^{-1}$ respectively. Moreover, the shoulder at $183-205 \mathrm{~cm}^{-1}$ is assigned to the vibration of $\mathrm{ZnO}_{6}$ units.

In previous papers [34-42], it has been established that MoOn polyhedral like $\mathrm{MoO}_{4}$ tetrahedral units and $\mathrm{MoO}_{6}$ octahedra units gave strong Raman bands. In the region $700-1000 \mathrm{~cm}^{-1}$, Raman bands corresponding to symmetric stretching modes $\left(v_{1}\right)$ and asymmetric stretching modes $\left(v_{3}\right)$ are observed. Yet, Raman bands attributed to symmetric bending modes $\left(v_{2}\right)$ and asymmetric bending modes $\left(v_{4}\right)$ are noticed in the wavenumber range of $300-520 \mathrm{~cm}^{-1}$ [26]. In figure 8 , the spectra's peak position of glasses containing molybdate oxide indicates that the strong band at $918-936 \mathrm{~cm}^{-1}$ could be attributed to the deformed vibrational mode of $\mathrm{MoO}_{6}[24]$. Beyond of $20 \%$ of $\mathrm{MoO}_{3}$, a partial conversion of $\mathrm{MoO}_{6}$ units to $\mathrm{MoO}_{4}$ units. This transformation is assisted by $\mathrm{Zn}^{+2}$ or $\mathrm{Zn}^{+3}$ [23]. We noticed that the intensity of $\mathrm{MoO}_{6}$ increases, whereas the band of $\mathrm{SbO}_{3}, \mathrm{ZnO}_{4}$ decreases may be the presence of $\mathrm{Mo}^{5+} \mathrm{O}_{3}{ }^{-}$complexes in the structural network of the glass series and generates the depolymerisation of zinc and /or antimonite chains in the vitreous samples [24]. Additionally, the $v_{1}$ and $v_{2}$ vibrational bands of monomeric $\mathrm{MoO}_{4}{ }^{2-}$ tetrahedral units have also been located at about 862-869 $\mathrm{cm}^{-1}$ and $327-346 \mathrm{~cm}^{-1}$ respectively.

For the $\mathrm{ZnO}-\mathrm{B}_{2} \mathrm{O}_{3}-\mathrm{MoO}_{3}$ system, Alexandrov et al [25] deconvolution of the Raman spectrum in the regions $600-1100 \mathrm{~cm}^{-1}$ into 6 peaks with positions at: $830,880,920$ and $950 \mathrm{~cm}^{-1}$, showing the presence of $\mathrm{Mo}^{6+}$ ions in $\mathrm{MoO}_{4}{ }^{2-}$ with more coordination, one peak at $780 \mathrm{~cm}^{-1}$ with isolated $\mathrm{MoO}_{4}$ units, and the last band corresponds to the 


\section{ACCEPTED MANUSCRIPT}

stretching vibration of $\mathrm{BO}_{4}$ at $1000-1200 \mathrm{~cm}^{-1}$. In our case, the spectra are fitted with a sum of Gaussian curves by means of the least square method as shown in Fig. 9, the deconvolution is performed in the same interval. We found three peaks at $780 \mathrm{~cm}^{-1}$ assigned to isolated $\mathrm{MoO}_{4}$ units, $860 \mathrm{~cm}^{-1}$ and $920 \mathrm{~cm}^{-1}$ indicate that $\mathrm{Mo}^{6+}$ ions are present in $(\mathrm{MoO} 4)^{2-}$ tetrahedral units for the glass sample SMZ20. The analysis of the spectra of SMZ30, SMZ40 and SMZ50 glasses shows the appearance of a new peak at $820 \mathrm{~cm}^{-1}$ in addition to the previous ones $\left(780,860\right.$ and $\left.920 \mathrm{~cm}^{-1}\right)$. Probably, this shows a structural change at $20 \%$ of molybdenum with the formation of $\mathrm{Mo}^{6+}$ ions in different coordination's, namely low symmetry, highly distorted, or isolated in $\mathrm{MoO}_{4}{ }^{2-}[26]$.

Finally, we notice that the Zinc chloride is involved in the vitreous network by $\mathrm{ZnCl}_{4}{ }^{-2}$ tetrahedra and as shown by the Raman analysis, zinc chloride portion becomes an oxide. The peaks at 233 and $275 \mathrm{~cm}^{-1}$ are assigned to the symmetric $\mathrm{Zn}-\mathrm{Cl}$ stretching vibrations in type A and B respectively [27]. The peaks are not resolved in this work because of the small amount of zinc chloride in the series of glasses and the intrinsic peak broadening of the Raman spectrum corresponding to the state of an amorphous solid (glassy state).

\subsection{Microhardness}

Microhardness $\left(\mathrm{H}_{\mathrm{V}}\right)$ was measured for all the samples, as shown in Fig. 10 the state of the microhardness curve is adjusted by the expansion of the $\mathrm{MoO}_{3}$ content. The evaluation is monotonic for the $\mathrm{MoO}_{3} / \mathrm{Sb}_{2} \mathrm{O}_{3}$ substitution, it drops from 229 to 172 $\mathrm{N} / \mathrm{mm}^{2}$ between 10 and $50 \mathrm{~mol} \%$. This evolution was explained by the variation of the bond strength and also the dissociation energy. The microhardness of the samples increases with the molybdenum content in the glasses, corresponding to a consolidation of the glass by an increasing of the Mo-O strength bonds. Furthermore, the 


\section{ACCEPTED MANUSCRIPT}

molybdenum enters in the glass network as a glass former and contributes to the formation of rigid structural units as well as strengthening the rigidity of the glass structure.

\subsection{Elastic properties}

Elastic moduli E, G, K have been calculated for the SMZ glass series. A general observation of these curves shows (Fig.11) that elastic moduli increase with the substitution of $\mathrm{Sb}_{2} \mathrm{O}_{3}$ by $\mathrm{MoO}_{3}$. There are several models for the interpretation of elastic moduli of oxide glasses. In literature, few studies referred to elastic moduli of oxychloride based antimonite Iezid et al. [9]. The series of glasses comprises $90 \%$ of the oxides and $10 \%$ of $\mathrm{ZnCl}_{2}$. This chloride has a low binding energy compared to oxides and we assume that the $\mathrm{ZnCl}_{2}$ effect on the elastic modulus is negligible. So, elastic moduli of oxide glasses apply in a good approximation in our case. The model of Mackashima and Mackanzi [28, 29] explains the Young's modulus by increasing the dissociation energy and the packing density factor following the increase in the content of $\mathrm{MoO}_{3}$.

The limited variation of shear modulus can be explained by the model of Bridge $\mathrm{B}$ et al [30]. We assume that the cross-link densities are run by an almost constant recovery among bridging oxygen and nonbridging, which limits the variation of G.

The evaluation of $\mathrm{K}$ can be explained by the Bulk compression model [30] in the sense that the insertion of $\mathrm{MoO}_{3}$ increases the stretching bond strength since the dissociation energy of $\mathrm{M}-\mathrm{O}$ is greater than $\mathrm{Sb}-\mathrm{O}$.

\section{Conclusion}




\section{ACCEPTED MANUSCRIPT}

A ternary glass system is synthesised and the broad vitreous area is observed in the $\mathrm{Sb}_{2} \mathrm{O}_{3}-\mathrm{MoO}_{3}-\mathrm{ZnCl}_{2}$ system. A glass samples in which $\mathrm{Sb}_{2} \mathrm{O}_{3}$ is substituted by $\mathrm{MoO}_{3}$ have been characterized. The differential scanning calorimetry analysis shows that all the compositions have a large thermal stability $\left(\mathrm{Tx}-\mathrm{Tg}>100^{\circ} \mathrm{C}\right)$. The IR transmission is spread out from the visible to infrared due to the low phonon energy of the antimonite. The general trend is that $\mathrm{MoO}_{3}$ incorporation leads to the decrease of density from 5.038 to $4.722 \mathrm{~g} / \mathrm{cm}^{3}$, glass transition temperature $\mathrm{T}_{\mathrm{g}}$ from 279 to $259{ }^{\circ} \mathrm{C}$ whereas the microhardness (172 to $229 \mathrm{~N} / \mathrm{mm}^{2}$ ) and the rigidity (elastic moduli) increases. The Raman spectroscopy provides the partial conversion of molybdenum ions from $\mathrm{MoO}_{6}$ octahedral to $\mathrm{MoO}_{4}$ tetrahedral positions from $20 \%$ of $\mathrm{MoO}_{3}$. The quality of these high stability glasses makes them a potential application for optoelectronic devices.

\section{Acknowledgements}

The support of the Authorities of the Laboratoire de Génie Mécanique, université de Biskra, Algeria, the Principal's New Initiative grant by the university of the West Indies, Mona campus, Jamaica and Lakireddy Bali Reddy College of Engineering (A), Mylavaram, A.P., India is highly acknowledged.

\section{References}

[1] M. Soltani, T. Djouama, A. Boutarfaia, M. Poulain, New heavy metal oxide glasses based on $\mathrm{Sb}_{2} \mathrm{O}_{3}$, J. Optoelectron. Adv. Mater. Symp.1 (2009) 339-342.

[2] M. Nalin, M. Poulain, M. Poulain, S.J. Ribeiro, Y. Messaddeq, Antimony oxide based glasses, J. Non-Cryst. Solids. 284 (2001) 110-116. 


\section{ACCEPTED MANUSCRIPT}

[3] M. Hamzaoui, M. Soltani, M. Baazouzi, B. Tioua, Z. Ivanova, R. Lebullenger, M. Poulain, J. Zavadil, Optical properties of erbium doped antimony based glasses: Promising visible and infrared amplifiers materials, phys. status solidi (b). 249 (2012) 2213-2221.

[4] M. Kubliha, M. Soltani, V. Trnovcová, M. Legouera, V. Labaš, P. Kostka, D. Le Coq, M. Hamzaoui, Electrical, dielectric, and optical properties of $\mathrm{Sb}_{2} \mathrm{O}_{3}-\mathrm{Li}_{2} \mathrm{O}-\mathrm{MoO}_{3}$ glasses, J. Non-Cryst. Solids. 428 (2015) 42-48.

[5] M. Soltani, M. Hamzaoui, S. Houhou, H. Touiri, L. Bediar, A. Ghemri, P. Petkova, Physical Characterization of $\mathrm{Sb}_{2} \mathrm{O}_{3}-\mathrm{M}_{2} \mathrm{O}-\mathrm{MoO}_{3}(\mathrm{M}=\mathrm{Li}, \mathrm{K})$ New Glasses, Acta Phys. Pol. A 123 (2013) 227-229.

[6] K. Ouannes, K. Lebbou, Brian-M. Walsh, M. Poulain, G. Alombert-Goget, Y. Guyot, New $\mathrm{Er}^{3+}$ doped antimony oxide based glasses: Thermal analysis, structural and spectral properties, J. Alloys Compd. 649 (2015) 564-572.

[7] L. Zan, J. Zhong, Q. Luo, New oxysulphide glasses from the $\mathrm{Sb}_{2} \mathrm{O}_{3}-\mathrm{Sb}_{2} \mathrm{~S}_{3} \cdot \mathrm{M}_{\mathrm{x}} \mathrm{S}$ system, J. Non-Cryst. Solids. 257 (1999) 396-399.

[8] R. Makhloufi, A. Boutarfaia, M. Poulain, New oxysulphide glasses in $\mathrm{Sb}_{2} \mathrm{~S}_{3}-\mathrm{M}_{\mathrm{m}} \mathrm{O}_{\mathrm{n}}$ and $\mathrm{Sb}_{2} \mathrm{~S}_{3}-\mathrm{Sb}_{2} \mathrm{O}_{3}-\mathrm{M}_{\mathrm{m}} \mathrm{O}_{\mathrm{n}}$ systems, J. Alloys Compd. 398 (2005) 249-255.

[9] M. Iezid, M. Legouera, F. Goumeidane, M. Poulain, V. Nazabal, R. Lebullenger, Glass formation in the $\mathrm{Sb}_{2} \mathrm{O}_{3}-\mathrm{CdCl}_{2}-\mathrm{SrCl}_{2}$ ternary system, J. Non-Cryst. Solids. 357 (2011) 2984-2988.

[10] F. Goumeidane, M. Legouera, M. Iezid, M. Poulain, V. Nazabal, R. Lebullenger, Synthesis and physical properties of glasses in the $\mathrm{Sb}_{2} \mathrm{O}_{3}-\mathrm{PbCl}_{2}-\mathrm{MoO}_{3}$ system, J. NonCryst. Solids. 357 (2011) 3572-3577.

[11] V. Himamaheswara Rao, P. Syam Prasad, P. Venkateswara Rao, L.F. Santos, N.Veeraiah, Influence of $\mathrm{Sb}_{2} \mathrm{O}_{3}$ on tellurite based glasses for photonic applications, J. Alloys Compd. 687 (2016) 898-905.

[12] P. Srinivasa Rao, P.M. Vinaya Teja, A. Ramesh Babu, Ch. Rajyasree, D. Krishna $\mathrm{Rao}$, Influence of molybdenum ions on spectroscopic and dielectric properties of $\mathrm{ZnF}_{2}$ $\mathrm{Bi}_{2} \mathrm{O}_{3}-\mathrm{P}_{2} \mathrm{O}_{5}$ glass ceramics, J. Non-Cryst. Solids. 358 (2012) 3372-3381.

[13] R.J. Short, R.J. Hand, N.C. Hyatt, An Investigation into the Oxidation State of Molybdenum in Simplified High Level Nuclear Waste Glass Compositions, Mater. Res. Soc. Symp. Proc. 757 (2003) 141-146.

[14] S. Rada, E. Culea, R. Chelcea, M. Rada, A. Bot, N. Aldea, V. Rednic, Physical properties and electrochemical performance of molybdenum-lead-germanate glasses and glass ceramics, Ceram. Int. 39 (2013) 1403-1411.

[15] M. Krapchanska, R. Iordanova, Y. Dimitriev, A. Bachvarova-Nedelcheva, Glass formation in the system $\mathrm{MoO}_{3}-\mathrm{TiO}_{2}-\mathrm{Bi}_{2} \mathrm{O}_{3}$, J. Optoelectron. Adv. Mater. 12 (2010) 1692-1695.

[16] J. Šubčík, L. Koudelka, P. Mošner, L. Montagne, B. Revel, I. Gregora, Structure and properties of $\mathrm{MoO}_{3}$-containing zinc borophosphate glasses, J. Non-Cryst. Solids. 355 (2009) 970-975.

[17] G. Poirier, C.B. de Araujo, Y. Messaddeq, S.J. Ribeiro, M. Poulain, Tungstate fluorophosphate glasses as optical limiters, J. appl. phys.91 (2002) 10221-10223.

[18] B. Bridge, N. Patel, The elastic constants and structure of the vitreous system MoPO, J. mater sci. 21 (1986) 1187-1205.

[19] B. Chowdari, P.P. Kumari, Studies on $\mathrm{Ag}_{2} \mathrm{OMxOy} \cdot \mathrm{TeO}_{2}\left(\mathrm{MxOy}=\mathrm{WO}_{3}, \mathrm{MoO}_{3}\right.$, $\mathrm{P}_{2} \mathrm{O}_{5}$ and $\mathrm{B}_{2} \mathrm{O}_{3}$ ) ionic conducting glasses, Solid State Ionics. 113(1998) 665-675.

[20] J. Yao, Y. Yang, B. Loo, Enhancement of photochromism and electrochromism in $\mathrm{MoO}_{3} / \mathrm{Au}$ and $\mathrm{MoO}_{3} / \mathrm{Pt}$ thin films, J.Phys. Chem. B. 102 (1998) 1856-1860. 
[21] R. Berger, P. Beziade, A. Levasseur, Y. Servant, Electron spin resonance of vitreous lithium boromolybdates, Phy. chem. Glasses. 31 (1990) 231-238.

[22] M. Volf, Mathematical approach to glass. 1988, Amsterdam, Elsevier.

[23] M. Milanova, R. Iordanova, L. Aleksandrov, M. Hassan, Y. Dimitriev, Glass formation and structure of glasses in the $\mathrm{ZnO}-\mathrm{Bi}_{2} \mathrm{O}_{3}-\mathrm{WO}_{3}-\mathrm{MoO}_{3}$ system, J. Non- Cryst. Solids. 357 (2011) 2713-2718.

[24] S.B.M. Krishna, A.R. Babu, RSree. Ch, D.Krishna Rao, Influence of molybdenum ions on the structure of $\mathrm{ZnO}-\mathrm{As}_{2} \mathrm{O}_{3}-\mathrm{Sb}_{2} \mathrm{O}_{3}$ glass system by means of spectroscopic and dielectric studies, J. Non-Cryst. Solids. 356 (2010) 1754-1761.

[25] L. Aleksandrov, T. Komatsu, R. Iordanova, Y. Dimitriev, Study of molybdenum coordination state and crystallization behavior in $\mathrm{MoO}_{3}-\mathrm{La}_{2} \mathrm{O}_{3}-\mathrm{B}_{2} \mathrm{O}_{3}$ glasses by Raman spectroscopy, J. Phys. Chem. Solids. 72 (2011) 263-268.

[26] L. Aleksandrov, T. Komatsu, R. Iordanova, Y. Dimitriev, Structure study of $\mathrm{MoO}_{3}$ $\mathrm{ZnO}-\mathrm{B}_{2} \mathrm{O}_{3}$ glasses by Raman spectroscopy and formation of $\alpha-\mathrm{ZnMoO}_{4}$ nanocrystals, Opt. Mater. 33 (2011) 839-845.

[27] K. Kinugawa, K. Kadono, H. Tanaka, Raman spectroscopic study on the structure of $\mathrm{ZnCl}_{2}-\mathrm{ZnX}_{2}$ and $\mathrm{ZnCl}_{2}-\mathrm{KX}(\mathrm{X}=\mathrm{Br}$, I) glasses, J. Non-Cryst. Solids. 110 (1989) 265272.

[28] A. Makishima, J. Mackenzie, Direct calculation of Young's modulus of glass, J. Non-Cryst. Solids. 12 (1973) 35-45.

[29] A. Makishima, J.D. Mackenzie, Calculation of bulk modulus, shear modulus and Poisson's ratio of glass, J. Non-Cryst. Solids. 17 (1975) 147-157.

[30] B. Bridge, A. Higazy, A model of the compositional dependence of the elastic moduli of polycomponent oxide glasses, Phys. chem. Glasses. 27 (1986) 1-14.

[31] Mogus-Milankovic, A., A. Santic, M. Karabulut, and D. E. Day. Study of electrical properties of $\mathrm{MoO}_{3}-\mathrm{Fe}_{2} \mathrm{O}_{3}-\mathrm{P}_{2} \mathrm{O}_{5}$ and $\mathrm{SrO}-\mathrm{Fe}_{2} \mathrm{O}_{3}-\mathrm{P}_{2} \mathrm{O}_{5}$ glasses by impedance spectroscopy, J. Non-Cryst. Solids. 330 (2003) 128-141.

[32] L. Bih, M. El Omari, JM. Reau, M. Haddad, D. Boudlich, A. Yacoubi, A. Nadiri, Electronic and ionic conductivity of glasses inside the $\mathrm{Li}_{2} \mathrm{O}-\mathrm{MoO}_{3}-\mathrm{P}_{2} \mathrm{O}_{5}$ system, Solid State Ionics. 132 (2000)71- 85.

[33] A. Delben, Y. Messaddeq, M.D. Caridade and M.A. Aegerter, Mechanical properties of ZBLAN glasses, J. Non-Cryst. Solids. 161 (1993)165-168.

[34] T. Sekiya, N. Mochida, S. Ogawa, Structural study of $\mathrm{MoO}_{3} \mathrm{TeO}_{2}$ glasses, J. NonCryst. Solids. 185 (1995) 135-144.

[35] M. Abe, Y. Benino, T. Fujiwara, T. Komatsu, R. Sato, Writing of nonlinear optical $\mathrm{Sm}_{2}\left(\mathrm{MoO}_{4}\right)_{3}$ crystal lines at the surface of glass by samarium atom heat processing, $\mathrm{J}$. Appl. Phys. 97 (2005) 123516-7.

[36] P. Becker, L. Bohaty, H.J. Eichler, J. Hanuza, A.A. Kaminskii, Observation of many-phonon stimulated Raman scattering and related cascaded nonlinear-laser effects in monoclinic $\mathrm{LaBO}_{2} \mathrm{MoO}_{4}$ single crystals, Laser Phys. Lett. 5 (2008) 114-121.

[37] L. Seguin, M. Figarz, R. Cavagnat, J.C. Lassegues, Infrared and Raman spectra of $\mathrm{MoO}_{3}$ molybdenum trioxides and $\mathrm{MoO}_{3} \cdot \mathrm{xH}_{2} \mathrm{O}$ molybdenum trioxide hydrates, Spectrochim. Acta A 51 (1995) 1323-1344.

[38] J. Hanuza, M. Maczka, K. Hermanowicz, P.J. Deren, W. Strek, L. Folcik, H. Drulis, Spectroscopic properties and magnetic phase transitions in Scheelite $\mathrm{MICr}$ $\left(\mathrm{MoO}_{4}\right)_{2}$ and Wolframite $\mathrm{MICr}\left(\mathrm{WO}_{4}\right)_{2}$ crystals, where $\mathrm{MI}=\mathrm{Li}, \mathrm{Na}, \mathrm{K}$, and Cs, J. Solid State Chem. 148 (1999) 468-478. 


\section{ACCEPTED MANUSCRIPT}

[39] T.T. Basiev, A.A. Sobol, Yu.K. Voronko, P.G. Zverev, Spontaneous Raman spectroscopy of tungstate and molybdate crystals for Raman lasers, Opt. Mater. 15 (2000) 205-216.

[40] G.D. Saraiva, W. Paraguassu, M. Maczka, P.T.C. Freire, J.A. Lima Jr, C.W.A .Paschoal, J.M. Filho, A.G.S. Filho, Temperature-dependent Raman scattering studies of $\mathrm{Na}_{2} \mathrm{MoO}_{4}$, J. Raman Spectrosc. 39 (2008) 937-941.

[41] J. Hanuza, M. Maczka, J. Lorenc, A.A. Kaminskii, L. Bohaty, P. Becker, Polarised IR and Raman spectra of non-centrosymmetric $\mathrm{Na}_{3} \mathrm{Li}\left(\mathrm{MoO}_{4}\right)_{2} \cdot 6 \mathrm{H}_{2} \mathrm{O}$ crystal-a new Raman laser material,J. Raman Spectrosc. 41 (2010) 424-430.

[42] C. Luz-Lima, G.D. Saraiva, A.G.Souza Filho, W. Paraguassu, P.T.C. Freire, J.Mendes Filho, Raman spectroscopy study of $\mathrm{Na}_{2} \mathrm{MoO}_{4} \cdot 2 \mathrm{H}_{2} \mathrm{O}$ and $\mathrm{Na}_{2} \mathrm{MoO}_{4}$ under hydrostatic pressure, J. Raman Spectrosc. 41 (2010) 576-581.

[43] G. Lakshminarayana, K.M. Kaky, S.O. Baki, A. Lira, P. Nayar, I.V. Kityk, M.A. Mahdi, Physical, structural, thermal, and optical spectroscopy studies of $\mathrm{TeO}_{2}-\mathrm{B}_{2} \mathrm{O}_{3}$ $\mathrm{MoO}_{3}-\mathrm{ZnO}-\mathrm{R}_{2} \mathrm{O}(\mathrm{R}=\mathrm{Li}, \mathrm{Na}$, and $\mathrm{K}) / \mathrm{MO}(\mathrm{M}=\mathrm{Mg}, \mathrm{Ca}$, and $\mathrm{Pb})$ glasses, Journal of Alloys and Compounds (2016), doi: 10.1016/j.jallcom.2016.08.180.

[44] G. Lakshminarayana, E.M.Weis, A.C. Lira, U. Caldiño, D.J.Williams, M.P.Hehlen, Cross Relaxation in Rare-Earth-Doped Oxyfluoride Glasses, J. Lumin. 139 (2013) 132142.

[45] W. A. Pisarski, J. Pisarska, R. Lisiecki, ł. Grobelny, G. D.-Dzik, W. R.Romanowski, Luminescence spectroscopy of rare earth-doped oxychloride lead borate glasses, J. Lumin. 131 (2011) 649-652.

Fig. 1. Glass formation in the $\mathrm{Sb}_{2} \mathrm{O}_{3}-\mathrm{MoO}_{3}-\mathrm{ZnCl}_{2}$ system.

Fig. 2. EDS spectra of glass sample SMZ20 oxychloride glass.

Fig. 3. DSC curves for the SMZ glasses (heating rate $20 \mathrm{~K} / \mathrm{min}$ ).

Fig. 4. Evolution of glass transition temperature versus molybdenum oxide concentration in the $(90-\mathrm{x}) \mathrm{Sb}_{2} \mathrm{O}_{3}-\mathrm{xMoO}_{3}-10 \mathrm{ZnCl}_{2}$ system.

Fig. 5. Infrared transmission of a $50 \mathrm{Sb}_{2} \mathrm{O}_{3}-40 \mathrm{MoO}_{3}-10 \mathrm{ZnCl}_{2}$ glass sample, $2.5 \mathrm{~mm}$ in thickness.

Fig. 6. UV-Visible transmission of a $50 \mathrm{Sb}_{2} \mathrm{O}_{3}-40 \mathrm{MoO}_{3}-10 \mathrm{ZnCl}_{2}$ glass sample, $2.5 \mathrm{~mm}$ in thickness.

Fig.7. Urbach plot of $50 \mathrm{Sb}_{2} \mathrm{O}_{3}-40 \mathrm{MoO}_{3}-10 \mathrm{ZnCl}_{2}$ glass sample.

Fig. 8. Raman spectra of SMZ glasses. 
Fig. 9. Peak deconvolution of Raman spectra of (90-x) $\mathrm{Sb}_{2} \mathrm{O}_{3}-\mathrm{xMoO}_{3}-10 \mathrm{ZnCl}_{2}$ $(\mathrm{x}=20,30,40$ and 50) glasses.

Fig. 10. Microhardness versus composition parameter $\mathrm{x}$ for SMZ glasses.

Fig. 11. Evolution of elastic moduli versus composition parameter $\mathrm{x}$ for SMZ glasses. $\mathrm{E}$ is Young's modulus, $\mathrm{K}$ is bulk modulus and $\mathrm{G}$ shear modulus.

Table 1. Composition and some experimental properties of SMZ glasses.

\begin{tabular}{|c|c|c|c|c|c|c|c|c|c|c|c|c|c|c|}
\hline \multirow{3}{*}{$\begin{array}{c}\text { Glas } \\
\mathbf{s}\end{array}$} & \multicolumn{5}{|c|}{ Nominal composition } & \multicolumn{6}{|c|}{ Analyzed composition } & \multirow{3}{*}{$\begin{array}{l}\mathrm{Hv} \\
\mathrm{N} / \mathrm{m} \\
\mathrm{m}^{2}\end{array}$} & \multirow{3}{*}{$\begin{array}{l}\rho \\
\mathrm{g} / \mathrm{c} \\
\mathrm{m}^{3}\end{array}$} & \multirow{3}{*}{$\begin{array}{c}\mathrm{V}_{\mathrm{m}} \\
\mathrm{cm}^{3} / \\
\mathrm{mol}\end{array}$} \\
\hline & \multicolumn{3}{|c|}{ Cation $\%$} & \multicolumn{2}{|c|}{$\begin{array}{l}\text { Anion } \\
\%\end{array}$} & \multicolumn{3}{|c|}{ Cation $\%$} & \multicolumn{3}{|c|}{ Anion $\%$} & & & \\
\hline & $\mathrm{Sb}$ & $\mathrm{Zn}$ & Mo & $\mathrm{O}$ & $\begin{array}{l}\mathrm{C} \\
1\end{array}$ & $\mathrm{Sb}$ & $\mathrm{Zn}$ & Mo & $\mathrm{Si}$ & $\mathrm{O}$ & $\mathrm{Cl}$ & & & \\
\hline SMZ & 88. & 5. & 5.5 & 93 & 6. & 86. & 6. & 6.6 & 0. & 79. & 20. & 172 & 5.0 & 11.03 \\
\hline 10 & 9 & 55 & 5 & .1 & 9 & 55 & 42 & 3 & 4 & 5 & 5 & & 38 & 1 \\
\hline SMZ & 82. & 5. & 11. & 93 & 6. & 82. & 5. & 11. & 0. & 85. & 14. & 194 & 4.9 & 10.78 \\
\hline 20 & 35 & 88 & 77 & .1 & 9 & 65 & 1 & 63 & 6 & 09 & 91 & & 7 & \\
\hline SMZ & 75 & 6. & 18. & 93 & 6. & 72. & 6. & 19. & 1. & 92. & 7.9 & 206 & 4.8 & 10.48 \\
\hline 30 & & 25 & 75 & .1 & 9 & 34 & 83 & 73 & 1 & 01 & 9 & & 92 & \\
\hline SMZ & 66. & 6. & 26. & 93 & 6. & 58. & 6. & 33. & 0. & 84. & 15. & 223 & 4.8 & 10.2 \\
\hline 40 & 66 & 67 & 27 & .1 & 9 & 95 & 8 & 75 & 5 & 86 & 14 & & 14 & \\
\hline SMZ & 57. & 7. & 35. & 93 & 6. & 55. & 8 & 35. & 0 . & 95. & 4.4 & 229 & 4.7 & 9.96 \\
\hline 50 & 15 & 14 & 71 & .1 & 9 & 87 & & 43 & 7 & 56 & 4 & & 22 & \\
\hline
\end{tabular}

Table 2. Characteristic temperatures $\left({ }^{\circ} \mathrm{C}\right)$ and thermal stability range of SMZ glasses: $\mathrm{Tg}$ for glass transition, $\mathrm{Tx}$ for onset of crystallization and $\mathrm{Tp}$ for exothermic maximum.

\begin{tabular}{cccccccc} 
Glass & $\mathrm{Sb}_{2} \mathrm{O}_{3}$ & $\mathrm{MoO}_{3}$ & $\mathrm{ZnCl}_{2}$ & $\mathrm{Tg}$ & $\mathrm{Tx}$ & $\mathrm{Tp}$ & $\mathrm{Tx}-\mathrm{Tg}$ \\
\hline $\mathrm{SMZ} \mathrm{10}$ & 80 & 10 & 10 & 279 & 401 & 426 & 122 \\
$\mathrm{SMZ} 20$ & 70 & 20 & 10 & 277 & 412 & 447 & 135 \\
$\mathrm{SMZ} 30$ & 60 & 30 & 10 & 274 & 466 & 479 & 192 \\
$\mathrm{SMZ} 40$ & 50 & 40 & 10 & 270 & 405 & 434 & 135 \\
$\mathrm{SMZ} \mathrm{50}$ & 40 & 50 & 10 & 259 & 376 & 402 & 117 \\
\hline
\end{tabular}




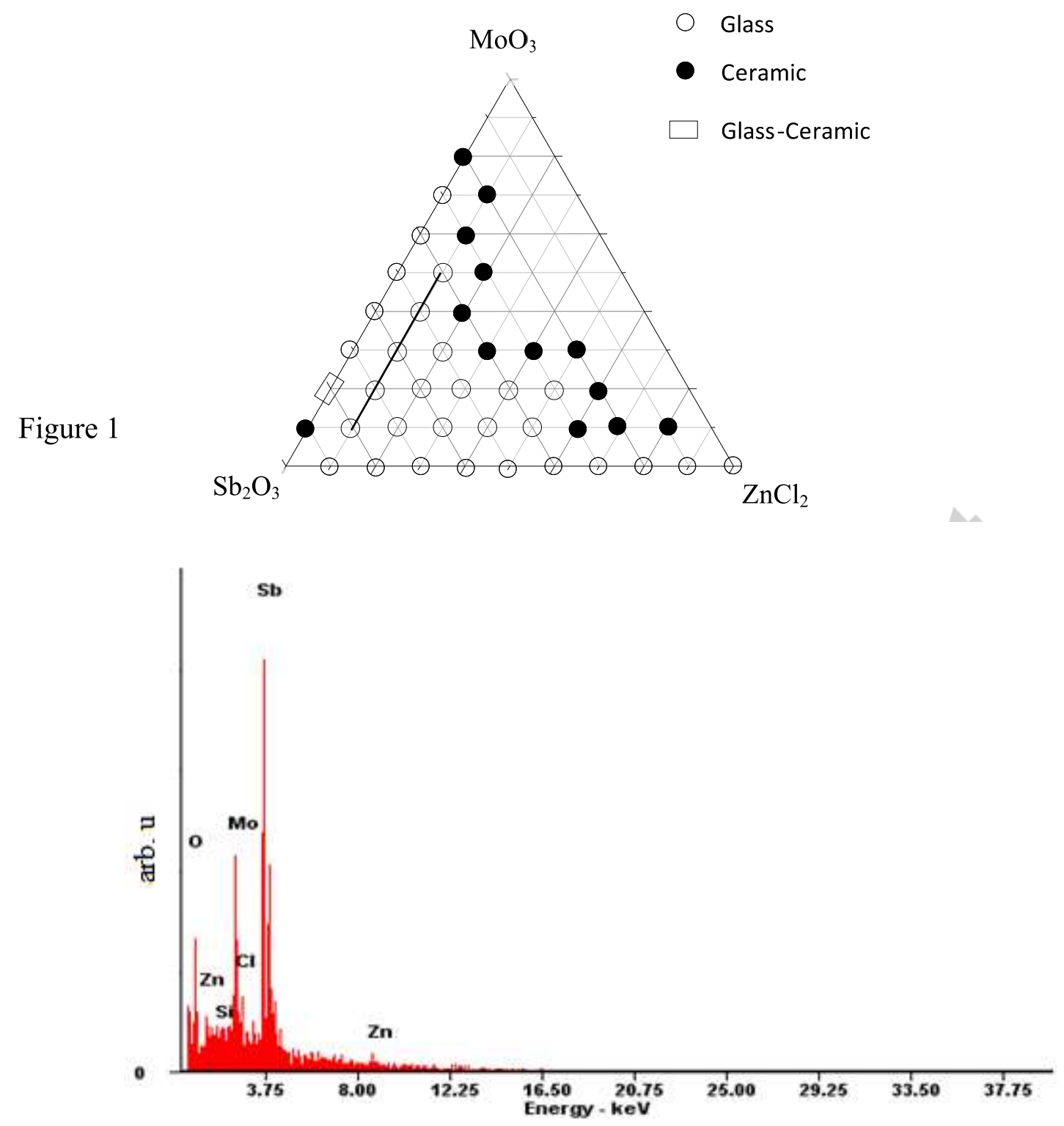

Figure 2 


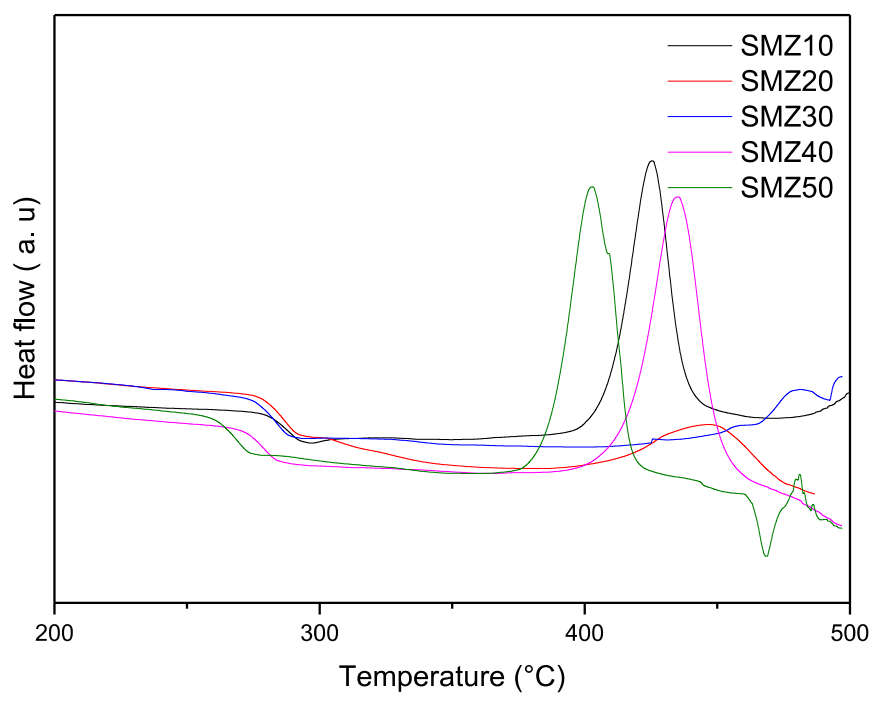

Figure 3

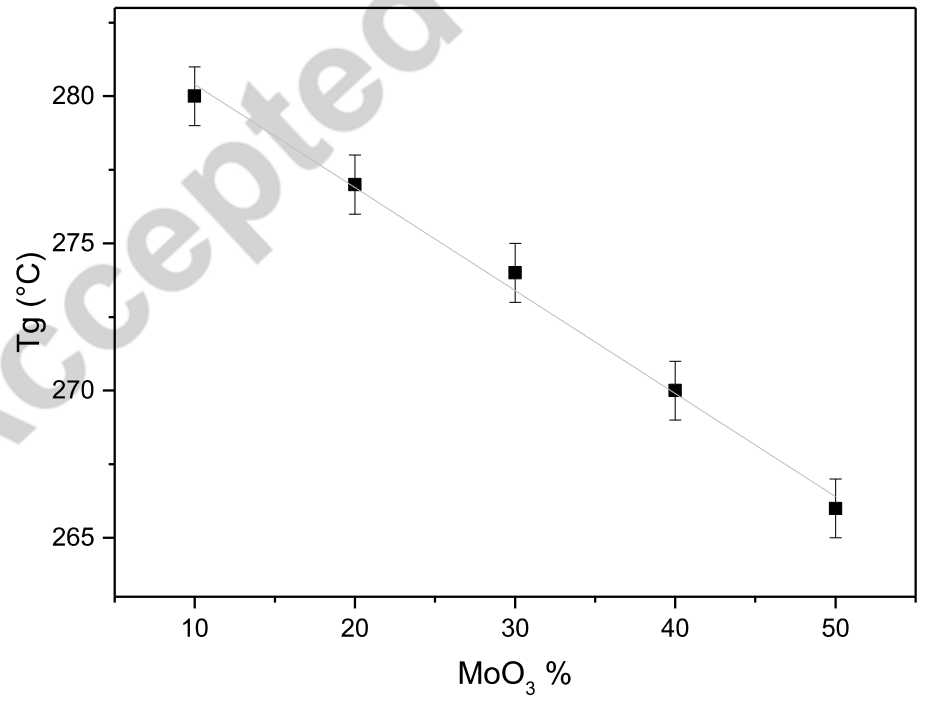

Figure 4 


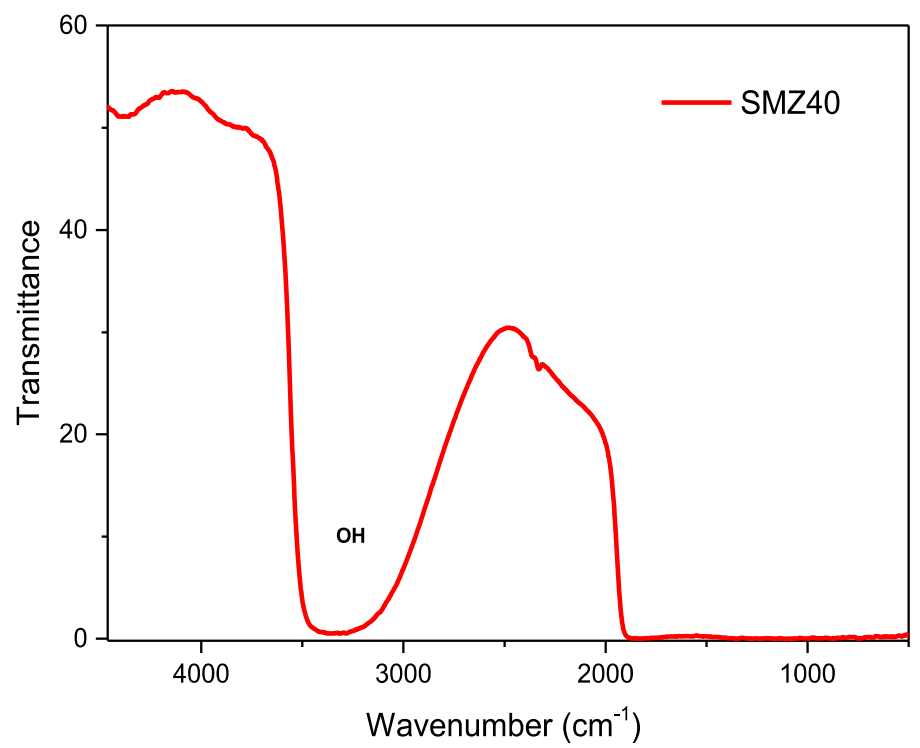

Figure 5

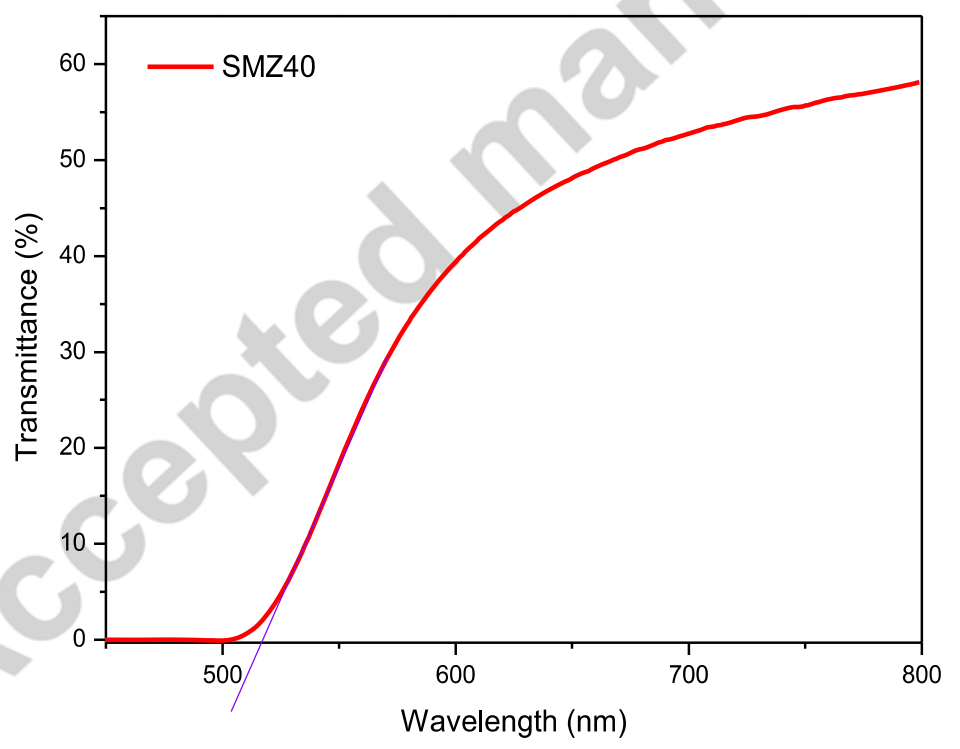

Figure 6 


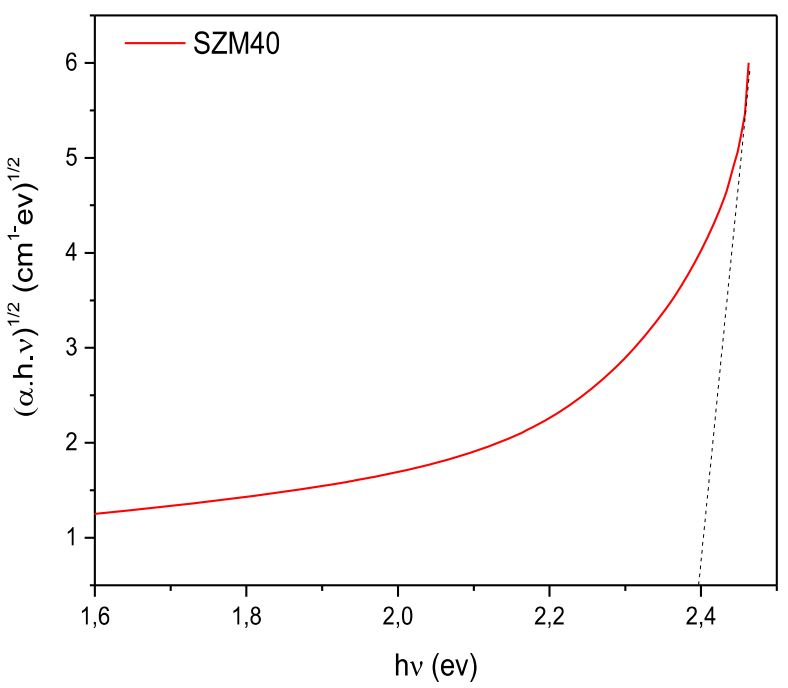

Figure 7 


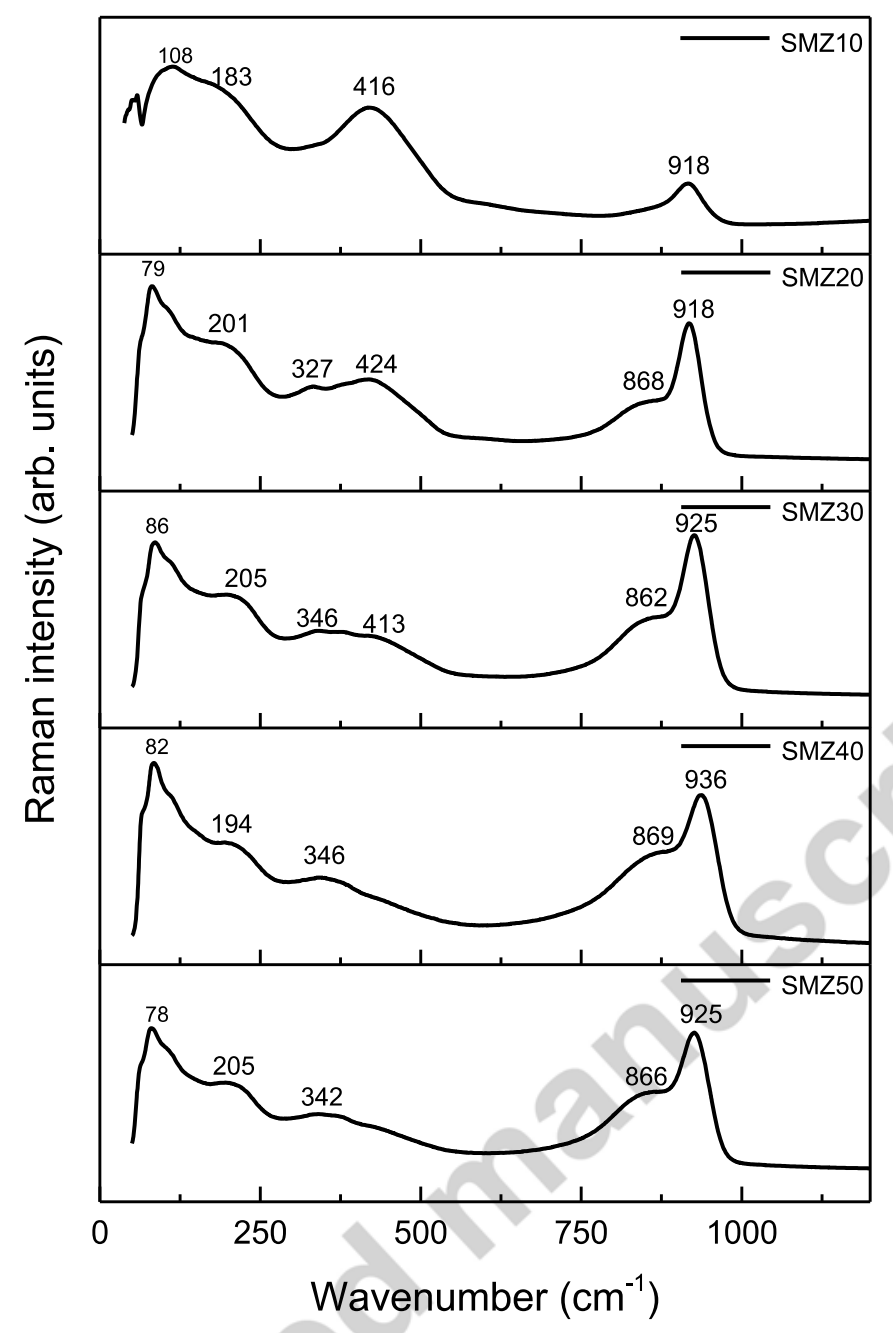

Figure 8 


\section{ACCEPTED MANUSCRIPT}
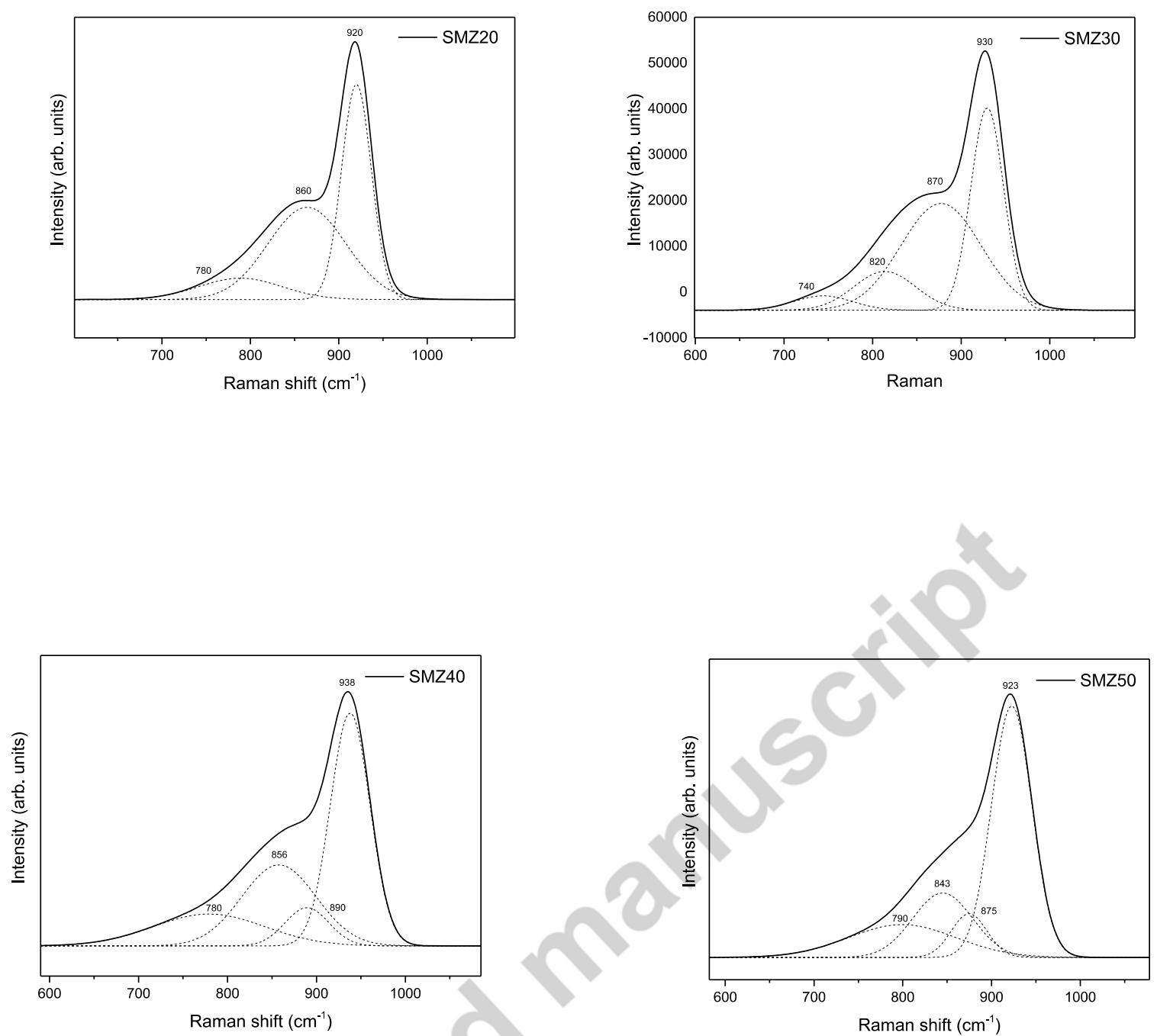

Figure 9 


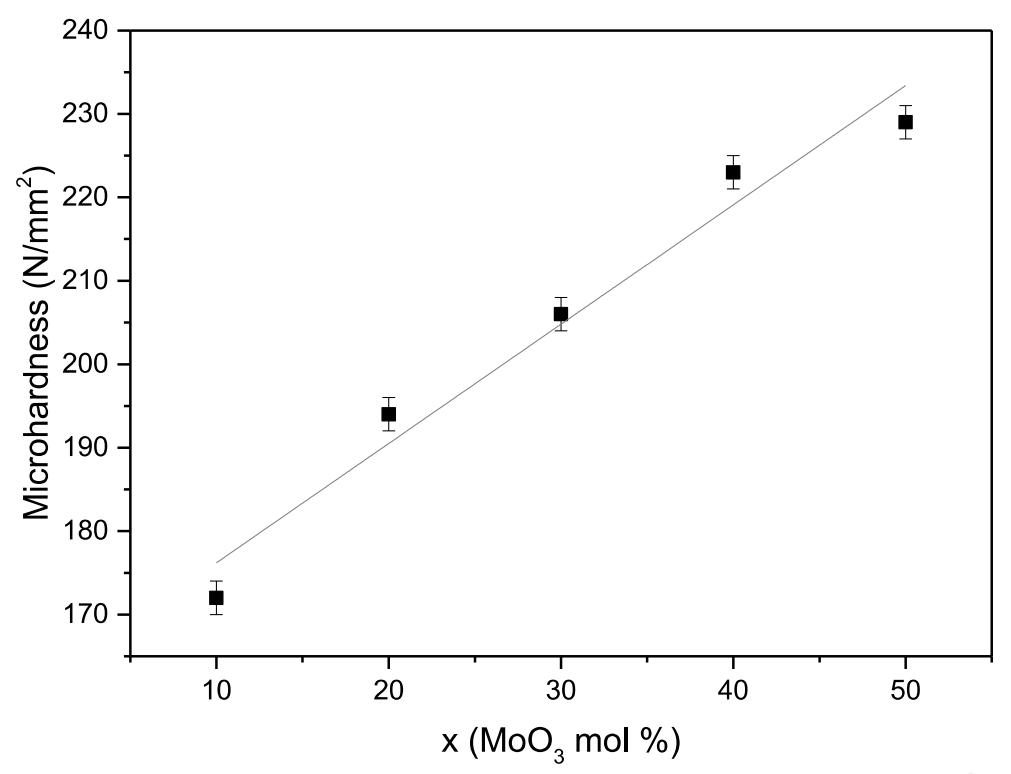

Figure 10

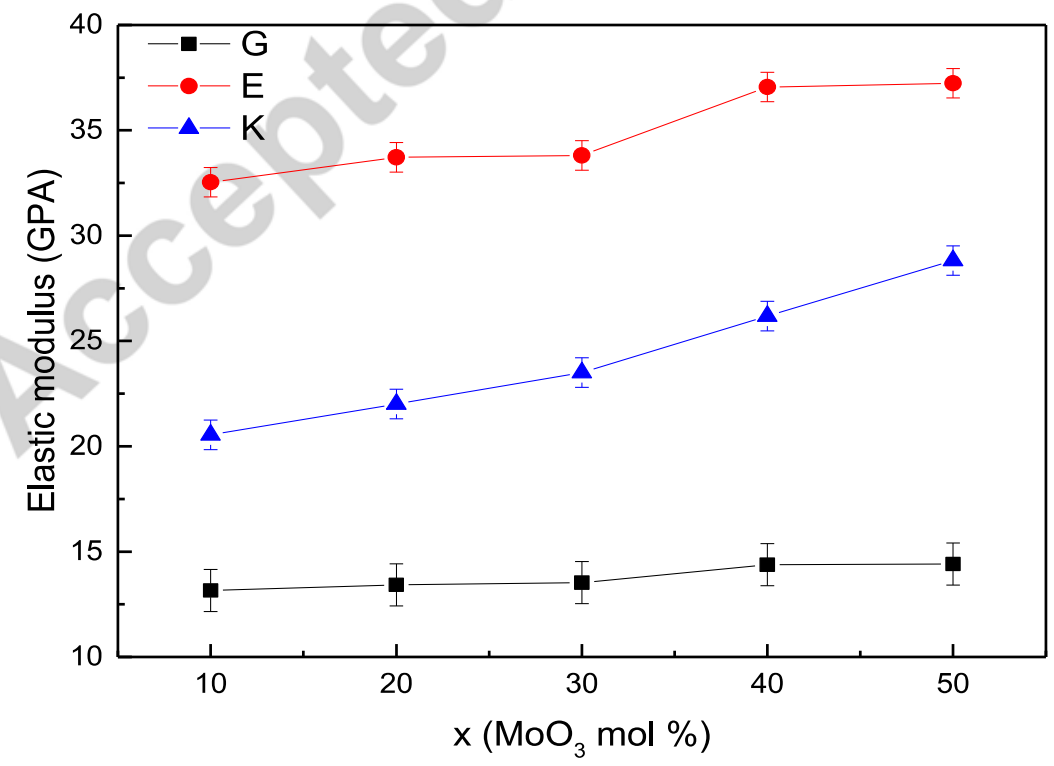

Figure 11 